\title{
Hoteliers' human resource strategies for business sustainability during Covid-19 pandemic in Ghana
}

\author{
Gabriel Dwomoh \\ Austin W. Luguterah \\ Solomon B. Duah
}

Department of Management Studies, Kumasi Technical University, Ghana

\author{
Keywords \\ COVID-19, HR strategies, hoteliers, business sustainability, Ghana
}

\begin{abstract}
The main objective underlying the study is to assess human resource strategies adopted by hoteliers in Ghana during the COVID-19 pandemic period and their sustainability. The target population of the study was 725 and this comprises of 471 and 254 hotels from Greater Accra and Ashanti regions, respectively. Using Guilford and Fruchter (1973) formula, a total sample size of 371 representing both regions was used for the study. The study shows that employees' lay off is considered as the main Human Resource (HR) strategy hoteliers in Ghana adopted during the COVID-19 pandemic period to salvage their businesses in terms of meeting employees wage bill though there were other HR strategies that could have been adopted. Among other HR strategies include operationalizing established pandemic fund, reducing employees working hours, temporary converting employees' full-time jobs to part time and re-training employees to use alternative means of doing business.

The study revealed that, the lack of interest for majority of hoteliers to pursue other HR strategies other than laying off their employees, was due to the absence of policies developed by the central government to support the implementation of the other HR strategies as pertains in countries such as Japan, Australia, Ireland, Canada, United States of America and France.

The originality of the study was based on the novel nature of the COVID-19 and the fact that, research has not been conducted on how hoteliers in Ghana are surviving through the use of HR strategies to salvage their businesses. The main limitation of the study was based on restrictive selection of only hotels in Ghana for the study though, there are different segments such as food and beverage, travel and tourism and recreation that completes the hospitality industry in Ghana.
\end{abstract}

Corresponding author: Gabriel Dwomoh

Email addresses for the corresponding author: gabdwumoo@yahoo.com

First submission received: $4^{\text {th }}$ June 2020

Revised submission received: $18^{\text {th }}$ June 2020

Accepted: $25^{\text {th }}$ June 2020

\subsection{Introduction}

The survival of companies depends on several factors and these can be either internal or external. External factors such as pandemics need drastic measures to be put in place in order to mitigate its negative effects since organizations have no control over them. Literature in Shuaib et al (2014) shows that pandemics can produce both psychological distress as well as debt burdens for owners of businesses. To the writers, the viability of businesses can be affected as a result of natural disasters. Forbes in 2014 reported the negative effects some past pandemics namely Ebola and H1N1 influenza had on businesses especially in the hospitality industry. Most planned holiday travellers had to cancel their trip and had to remain in their home countries because of the recommendations from the World Health Organization (WHO).

The recent pandemic which many scholars believed originated from China popularly known as COVID-19 has brought restrictions and how businesses should be conducted. WHO recommendations coupled with the Government of Ghana directives on social distancing, staying at home, avoiding crowded places and using cashless system of payment had impacted negatively on the customer base of businesses especially in the Ghana hospitality industry because of the temporal ban on inbound and 
outbound flights. In addition to this, non-critical industries within the two major cities in Ghana namely Kumasi and Accra were also suspended temporally from operating. In the hospitality industry, businesses were asked to operate but only under strict hygienic conditions. According to Novak (2017), though there are many services offered by the hospitality industry, conferences play a major role as they contribute significantly to the revenue this industry generates. All the services which include food and beverage, accommodation, travel, and recreation are all embedded in conferences and as such hotels need to pay much attention to this service.

Talking a clue from this literature, one will find it difficult to comprehend how the hospitality industry especially hotels are surviving vis-à-vis maintaining their human resource taking into consideration the suspensions of conferences at physical locations due to the COVID-19 pandemic. For instance, literature available at emarketer.com reported on March 14, 2020 shows that many high profile conferences to be organized by Facebook, Google and IBM had to be cancelled because of this pandemic and this has negatively affected the revenue of many businesses in the hospitality industry. This negative effect on the industry according to Voykto (2020) has forced many businesses in the industry to lay off workers because of the burden of meeting the wage bill of their workers. Some of the companies reported by the writer who have decided to use layoff as a strategy to salvage their businesses include hotels such as Camel Valley Ranch, Carlyle and Plaza Hotels, Claremont Hotel Properties, Four Seasons Hotel, Eden Roc Hotel, The Palace Hotel, Pebblebrook Hotel Trust and Sage Hospitality Trust all operating within the United States of America.

In Ghana, the situation is not different as according to the Minister of Finance, which was reported on myjoyonline.com April 3, 2020 there is no doubt that the COVID-19 is affecting the hospitality industry. To him, the occupancy rate of hotels in Ghana is $5 \%$ to $20 \%$ and there is major layoff in this industry as many hotels and other businesses within the industry cannot afford the remuneration of their employees. In citing an example, Kempinski Hotel which is one of the few 5-star hotels in Ghana had to lay off about $85 \%$ of their staff whilst Accra City Hotel decided to completely shut down their operations to the public due to unsustainability of compensation to be paid to their staff.

Apart from laying off employees as a key strategy by the players within the hospitality industry to salvage their businesses, many of these firms also expect governments to provide them with financial assistance if they are to remain in business. Countries such as Ghana, Canada, Nigeria, South Africa, and United States of America have made some funds available which businesses including those in the hospitality can access and pay back after some years. In the Republic of Ireland, support for businesses during this pandemic is even greater as the Government introduced a wage subsidy scheme to support employers by paying up to $70 \%$ of employees' wage. This support is to enable employers meet the wage bill of their employees and avoid layoffs.

With pandemics such as COVID-19 having strong correlation with employees layoff based on the above literature, one is tempted to ask many questions which some may include whether layoff is the only viable strategy firms in the hospitality industry can adopt to sustain their businesses during the Pandemic period? Are there equally viable human resource planning strategies firms in the hospitality industry are adopting? During period of pandemics, should firms within the industry look up to governments for support as the only means by which they can salvage their employees from been laid off? These are questions that this paper seeks to provide answers and as such looks at other human resource planning strategies and their adaptation by hoteliers within the hospitality industry with particular reference to Ghana.

\subsection{Literature review}

The hospitality industry is one of the oldest industries in the world and continue to be relevant to the economies of countries (Ottenbacher, Harrington and Persa, 2009). According to Jones (2002), hospitality industry dates to the earliest times of inn keeping that provided accommodation, food, and beverage services to travellers. The industry has close relationship with the tourism industry as its main focus has been to serve tourist and make them feel away from home. The industry is estimated to employ about 10 per cent of the global workforce both directly and indirectly. In the United Kingdom, for example, the industry contributes about $£ 36.1$ billion to the economy and employs 2.4 million people directly (Partington, 2016). In Ghana, the tourism and hospitality sector are seen as a major potential 
engine of growth and development. The ability of this industry to generate employment and reduce poverty has never been underestimated. It is said to be the fastest growing sector in the Ghanaian economy and the fourth major contributor, injecting over 6 per cent of the Gross Domestic Product. (Mensah-Ansah et al. 2014; Mensah 2011; Sarkodie and Adom 2015). Mensah-Ansah et al (2014) indicated that the hospitality and tourism industry increased the number of direct and indirect jobs from 234,679 to 330,514 , especially with international tourist arrivals increasing from 698,069 in 2008 to 1,080,220 in 2011, with a corresponding increase from US\$1.4 Billion to US\$2.1 Billion.

In recent years, the aggressive move by governments to boast tourism activities in Ghana, has invariably increased the activities of the hospitality industry. The increase in tourism, has created more businesses in the hospitality industry in Ghana and therefore has generated income through wages to many people (Adu-Ampong, 2019). The relationship between pandemic and countries hospitality sector can be described as detrimental. According to Kongoley (2015), the 2014- 2015 Ebola virus outbreak in countries such as Guinea, Liberia and Sierra Leone has had a negative impact on the tourism and hospitality industry, particularly in Sierra Leone. Again, the outbreak of SARS virus in 2003, created an unbearable impact on the growth of tourism in China (Zeng, et al., 2005). Also, when WHO declared Zika virus as public health emergency of international concerns in 2016, many countries especially Brazil and other South American countries felt the impact in their hospitality industry (Jamil, et al., 2016). In 2018, Nipah virus spread widely in Kerala, one of the states of India, a well-known for tourist friendly region. This negatively affected the hospitality industry in India (Sirajudeen, et al. 2020).

In Ghana, the rise in tourism has greatly influenced the economic growth of the hospitality industry but recently this trend is affected by the COVID-19. COVID-19 with its associated health protocols, have impeded human movement, and the cancellation of domestic and international flights in Ghana. According to Asiamah (2018), 80\% of the clientele of Ghana hospitality industry are predominately from Europe and United States of America. Therefore, the cancellation of flights and the called by WHO to observe health protocols, especially social distancing, have negatively affected the economic fortune with the hospitality industry in Ghana been forced to lay workers off.

The partial lockdown imposed in some cities in Ghana and the restriction of human movement, have created a precarious business climate for restaurants, bars, cafes, and other businesses dependent on guests. These are making it difficult for restaurants, hotels, and bars to breakeven, hence job losses (Agyeman, Laar and Ofori-Asenso, 2020). With the impact of social distancing, the hospitality industry will have to learn to function in a way not seen before. This invariably breaks the relationship between the industry and its clients. The more gap in relationship between the industry and its client, the more the industry loses money and cannot breakeven. This new practice of service delivery in hospitality industry affects the wages of employees. The cash flow within the hospitality industry has dropped significantly and has made it difficult for sustainable wage (Agyeman, Laar, and Ofori-Asenso, 2020). According to Barua (2020), the United States of America (USA) is estimated to have 8.3 million Americans employed by the hotel industry, with $85 \%$ being paid hourly. The COVID- 19 pandemic has caused a drastic drop of $71 \%$ in hours worked over the first two weeks. Meanwhile, the volume of employee layoffs over the same period has increased by nearly $470 \%$. In Ghana however, most hotels have closed down within the period of the lockdown, whilst others have strategically maintained skeletal staff due to the inability to sustain the wages of staff. Those on skeletal staff have resorted to home ('take away') delivery services, which is not popular among Ghanaians (Barua, 2020).

On a business level, the impact of the COVID-19 pandemic has reached every industry in the world, with the hospitality industry especially the tourism, taking a massive hit. According to OAG Aviation Worldwide, the travel restrictions on international flights have caused the global airline industry to lose huge sums of money amounting up to $\$ 880$ billion (Barua, 2020). Many hotels are empty and finding it difficult to attract clientele. Nevertheless, the grave situation has given space for worldwide solidarity with many hotels around the world providing their premises to house medical staff, first responders, or hospital patients not suffering from coronavirus. Literature from Koh (2020) shows that the hospitality industry is among the hardest hit due to fears of community spread through travel and group environments. The postponement and cancelation of events, conferences, conventions, and sports leagues has affected travel and tourism for business and pleasure. People who would have 
hitherto traveled for business conferences or pleasure are limited in movement, and therefore cannot go. The effect of the COVID-19 pandemic on the income of employees of the hospitality industry, has been grievous. In Ghana, the hotel association has called for some form of financial assistance from the government to help pay staff salaries as there are limited activities to make money. The association would even welcome the government decision to meet hotels halfway (https://www.myjoyonline.com/business/economy).

Though many researchers have argued strongly about the relationship between pandemics and firms in the hospitality industry adopting layoff as a key strategy to salvage their businesses, in the opinion of Naktiyok and Halis (2002) supported by Zehir and Savi (2004), finding ways of reducing cost has been with organizations over the years and businesses do not wait for pandemics to occur before layoff is considered as antidote to salvage businesses. In their argument, pandemics also have their good side and depending on the strategy adopted by firms, it may be considered as a booming period for firms especially in the information technology industry to employ more workers to meet the demand of their customers. Preko (2020) in adding to the literature of pandemics and employee's layoff also supported the argument that even in the hospitality industry, pandemics such as the COVID-19 can be an opportunity for hoteliers to turn their businesses around. According to the author, when pandemics occur, firms that can find ways of reaching out to their customers to provide service receives their loyalty and even get more referrals from customers and that can increase the demand of their services. The above literature points out that there are different views on how scholars see pandemics and its effect on employees in terms of layoff. Based on these divergent views and the related literature reviewed on the relationship between pandemics and employee's layoff, we can propose that:

Ho: There is no association between pandemics and layoff in the hospitality industry

Ha: There is association between pandemics and layoff in the hospitality industry

\subsection{Research methodology}

The main objective underlying this study is to examine the various human resource strategies adopted by hoteliers for business sustainability during the period of COVID-19 pandemic with particular reference to Ghana. The study was conducted between early January to late April 2020 when COVID-19 became an issue globally and Ghana realized the need to pay more attention to this pandemic. Though there are sixteen regions in Ghana, the researchers purposively selected Ashanti and Greater Accra Regions for the study since they were the regions with the most confirmed cases of the Coronavirus pandemic as at March 2020 when data was collected. The researchers adopted survey and case studies methodologies for the study and these two are not mutually exclusive since the study used structured questionnaire with telephone interviews to obtain data from respondents in different organizations.

The researchers used the whole month of March 2020 to collect data from hoteliers in relation to the COVID-19 and its effect on their businesses and employees. The respondents' response together with reviewed related literature, provided the bases for the researchers to arrive at their findings from which conclusions were drawn to contribute to the existing literature.

\subsection{Population and determination of sample size}

The study used only hotels in Greater Accra and Ashanti Regions since as already indicated, they were the regions with most confirmed cases of the pandemic at the time of the study. The target population was 725 and this comprises of 471 hotels in Greater Accra (GA) and 254 in Ashanti (AS) regions of Ghana ranging from 1 star to 5 stars. The researchers obtained the Population by surfing the internet to know the hotels in these two regions through travel.jumia.com/gh which is a very popular website that hosts hotels in the country.

In determining the sample size $(\mathrm{n})$ out of the population $(\mathrm{N})$, the researchers adopted Guilford and Fruchter (1973) formula as can be seen below:

$$
\mathrm{n}=\frac{\mathrm{N}}{1+\mu^{2} \mathrm{~N}}
$$

Where: $\mathrm{N}$ is the size of the population, $\mu$ is alpha $=0.05$. 
Therefore, Sample size (n) for GA:

$$
=\frac{471}{1+0.05^{2} \times 471}
$$

Based on the formula, the sample size for hotels in Greater Accra Region is $n=216$

Sample size (n) for AS:

$$
=\frac{254}{1+0.05^{2} \times 254}
$$

Based on the formula the sample size for hotels in Ashanti Region is $\mathrm{n}=155$

Total sample size: $(n: G A)+(n: A S)=371$

\subsection{Sampling techniques and instruments}

In getting respondents for the study based on the calculated sample size (n) for both regions, the names of the hotels extracted from the Jumia travel Ghana website were coded using numbers after which simple random sampling technique in the form of lottery method was used randomly to select the 371 hotels for the study. The researchers gave themselves a month for data collection and in order to achieve this, one of the researchers focused on collecting data from hotels in Ashanti Region whilst the other researcher concentrated on hotels in the Greater Accra Region. Estimated target of data collection from 14 hotels a day, for 27 days was agreed by the researchers to cover for all the 371 hotels.

Since the researchers envisaged that data collection at this period of pandemic will be difficult, the researchers adopted the mystery customer strategy to establish good relationship with the sampled hotels. With this strategy, the researchers with hidden motive pretended that they were looking for accommodation for some guests they were expecting and this paved the way for the sampled hotels to share information including the effect of the coronavirus pandemic on their businesses and employees as well. In most cases, indirect questions were asked and through the research experience of the authors, answers were deduced from the responses provided by the respondents.

The main data collection instrument used was questionnaires and using purposive sampling technique, these questionnaires were directed to the managers or assistant managers of the hotels where appropriate. The questionnaires were completed by the researchers based on the answers given by the respondents through telephone interviews which lasted averagely for about 13 minutes. Adopting this method of data collection helped in avoiding physical contact between the researchers and the respondents. The adoption of this strategy apart from the Ghana Government's directive for everyone to observe social distancing was also seen as the simplest way to collect data during the period of COVID19. The questions asked centred on the various human resource strategies adopted by hoteliers in sustaining their business, their perception of government support during the pandemic and lastly whether their preferred or chosen human resource strategy during the pandemic has helped them to achieve their objective in terms of business sustainability. Data was also collected from the respondents to solicit their views on whether during past and current pandemics, specifically Ebola virus outbreak in 2013 and Coronavirus in 2019, employees were laid off. The researchers used statistical technique in the form of chi square to test if there is any relationship between pandemics and employee's layoff in the hospitality industry, specifically hotels and this was at 5\% significance level. Data extracted from the questionnaires were represented by tables. The calculated chi square together with other findings of the study were used to arrive at conclusions and also contribute to the existing literature.

\subsection{Analysis of data and discussions}

The main objective underlying the study is to assess human resource strategies adopted by hoteliers in sustaining their businesses during pandemics, specifically the COVID-19. All businesses irrespective of their strength and size tend to be affected by the coronavirus pandemic and as Thunstrom et al (2020) pointed out, firms that are able to put measures in place tend to gain more from such pandemics through innovative ways of reaching out to their customers. Pandemics do not only affect businesses performance in terms of profit, sales, and growth but employees who provide the service as well. The hospitality industry though is considered as one of the largest industries in Ghana and one of the most perceived affected by the coronavirus pandemic, it is prudent to assess how the industry particularly hoteliers are managing their human resource to ensure business sustainability since greater 
part of the cost incurred by them goes into the payment of wages and salaries. The researchers in determining the various human resource strategies adopted by firms in the industry during the period of COVID-19, conducted a telephone interview to ascertain the various strategies used by hoteliers to salvage their businesses during the pandemic. Data extracted from the interview which were collated can be presented in the table below:

Table 1: Prime human resource strategies for business sustainability

\begin{tabular}{|l|c|c|}
\hline Strategy & Frequency & Percentage \\
\hline Compulsory annual leave & 23 & 6.2 \\
\hline Operationalizing established pandemic fund & 0 & 0.0 \\
\hline $\begin{array}{l}\text { Re-training employees to use alternative source of } \\
\text { doing business }\end{array}$ & 2 & 0.54 \\
\hline Reducing working hours & 15 & 4.04 \\
\hline Encouraging early voluntary retirements & 0 & 0.0 \\
\hline Laying off employees & 292 & 78.71 \\
\hline $\begin{array}{l}\text { Suspension of contract service providers and } \\
\text { assigning their services that are not technical to } \\
\text { permanent staff }\end{array}$ & 5 & 1.35 \\
\hline Converting employees' full-time job to part-time & 3 & 0.81 \\
\hline Expecting financial support from government & 25 & 6.74 \\
\hline Temporal closure of business & 6 & 1.62 \\
\hline Total & 371 & 100 \\
\hline
\end{tabular}

Source: Researchers fieldwork, 2020

From table 1, it can be seen that the top three HR strategies adopted by hoteliers to salvage their businesses during the period of COVID-19 includes employees layoff, getting the government to support their businesses and lastly asking employees to go on compulsory annual leave. Among all of these, laying off employees was considered as the major HR strategy hoteliers in Ghana adopted in order to ensure that they stay in business as can be witness in the table above. To the surprise of the researchers, two important strategies which were encouraging employees to go on early retirement and operationalizing established pandemic fund during the period of COVID-19 did not receive any support from all the respondents as none of the respondents claimed to be adopting these HR strategies. These findings clearly support the literature by Investor's Business Daily (2020) that, employees layoff has become the language that most businesses are using in order to enable them meet statutory expenditures such as the payment of employees' wages and salaries.

In the case of establishing pandemic fund, despite the awareness created by the World Bank in 2017 about the need for countries to adopt this strategy during periods of pandemics, countries such as Ghana have failed to develop relevant policies that will encourage firms to establish such fund. It is therefore not surprising that hoteliers have not adopted this strategy as a way of salvaging their businesses during such period of COVID-19. The literature by the World Health Organization (2018) actually contradicts this research findings as the writer claims this fund which normally takes the form of insurance is now becoming popular in the advance countries and many businesses in Europe and America are now appreciating the need to insure their businesses against pandemics. Looking at this contradiction, one can attribute it to the lack of knowledge and the importance organizations in developing countries such as Ghana attribute to insurance products as a way of safeguarding their businesses. The need to buy insurance products is still at the infancy stage in Ghana and it will not be surprise if hoteliers do not see the need to insure their businesses against pandemics.

With regard to hoteliers encouraging employees to go on voluntary retirements not receiving any support from the respondents as an HR strategy to be adopted by hoteliers during the period of COVID19, the literature provided by Shultz et al (1999) supports this findings. According to them, the hotel industry provide services and because there is high customer/employee contact, most hoteliers prefer engaging young but well cultured employees between the ages of 18 to 35 that can meet the expectations of diverse customers that patronize in the services of these hotels. In light of this, adopting this strategy to reduce the number of organization's workforce will not be appropriate. Again, this strategy normally 
works best as HR strategy when a significant number of the workforce are nearly towards their retirement age with the organization.

Since there are vast literature on the relationship between layoff of organizations employees and pandemic, the researchers wanted to test this available literature and its applicability in the hotel industry in Ghana. In doing this, the researchers extracted data obtained from telephone interviews with the respondents used for the study. The data centered on pandemics using COVID-19 and the Ebola virus outbreak as the basis and its relationship with employees' layoff by hoteliers who participated in the study. The results of the study based on the calculated chi square to determine the relationship between the two variables can be shown on the table below:

Table 2: Relationship between pandemics and employee's layoff

\begin{tabular}{|l|l|l|l|}
\hline External factor & Employee layoff & No Employee layoff & Marginal Row Totals \\
\hline Pandemic & 200 & 171 & 371 \\
\hline No Pandemic & 150 & 221 & 371 \\
\hline Marginal Column Totals & 350 & 392 & 742 (Grand Total) \\
\hline
\end{tabular}

Source: Researchers fieldwork, 2020

$X^{2}=13.52, \mathrm{p}<.05$

The calculated $\chi^{2}$ with $5 \%$ level of significance and at 1 degree of freedom shows that a relationship exists between pandemics and employee's layoff in the hotel industry in Ghana. This buttresses the many existing literature such as Dewitt (2017) and Davidson (2016) where studies conducted in different countries revealed similar relationship between pandemics and employees' layoff. This again supports the findings in table 1 where hoteliers were asked the main HR strategies adopted by their firms to salvage their businesses during the period of COVID-19. Since the outbreak of the coronavirus pandemic, literature provided by Roughan (2020) suggests that many countries such as Australia, New Zealand, United Kingdom, Republic of Ireland, Germany, Ghana and Canada have provided support to businesses especially the small and medium enterprises in view of salvaging their businesses so that employers will consider laying off their employees as the last option.

In Ghana, taking into consideration the policy by the Government to promote and support micro, small and medium scale enterprises during the pandemic period, there was the need for the researchers to seek the opinion of the respondents, government's support for firms in the hotel industry during the period of COVID-19. The perception of the respondents on government's support to businesses in the hotel industry can be presented in the table below:

Table 3: Perception of government support

\begin{tabular}{|l|l|l|l|l|l|l|l|}
\hline Perception of support & $1^{*}$ & $2^{*}$ & $3^{*}$ & $4^{*}$ & $5^{*}$ & Mean & $\begin{array}{l}\text { Overall } \\
\text { ranking }\end{array}$ \\
\hline Excellent & $8.0 \%$ & $11.0 \%$ & $30.0 \%$ & $16.0 \%$ & $35.0 \%$ & 3.612 & 5 \\
\hline Very good & $10.0 \%$ & $5.1 \%$ & $33.0 \%$ & $14.0 \%$ & $37.9 \%$ & 3.814 & 2 \\
\hline Good & $2.0 \%$ & $20.5 \%$ & $13.0 \%$ & $12.0 \%$ & $52.5 \%$ & 4.012 & 1 \\
\hline Average & $13.1 \%$ & $15.0 \%$ & 31.9 & $1.5 \%$ & $36.5 \%$ & 3.732 & 3 \\
\hline Poor & $16.0 \%$ & $20.1 \%$ & $21.2 \%$ & $7.6 \%$ & $35.1 \%$ & 3.635 & 4 \\
\hline
\end{tabular}

${ }^{*} 1$ = Strongly disagree; 2 = Disagree; 3 = Neutral; 4 = Agree; 5 = Strongly Agree

Source: Researchers fieldwork, 2020

The overall ranking of the respondents' perception on government support to businesses in the hotel industry shows that, hoteliers are satisfied with the support provided by the government but believes that more can be done. In the view of the respondents, the provision of water, electricity subsidies and tax reliefs by the Ghana Government for a four month period and the provision of loan facilities for businesses in Ghana are not enough for firms in the hotel industry to survive during the turbulent period of COVID-19. Looking at the respondents perception on Ghana government support for businesses in the hotel industry and the report by the Organization for Economic Co-operation and 
Development (OECD) in 2020, the researchers believe that for any of the HR strategies adopted by hoteliers in Ghana to achieve its goal, government support to aid firms in the industry to successfully implement these strategies is critical. For instance, in Japan, the government is supporting businesses through financial assistance up to JPY 1 million for firms to procure equipment and install telework facilities. From this financial assistance, it is believed that it will motivate firms to adopt the HR strategy of using information technology as alternative way of doing businesses during the period of COVID-19.

Apart from this, for hoteliers to successfully adopt HR Strategy of encouraging employees to proceed on annual leave during COVID-19, provision of financial assistance by the Government is also necessary in order for hoteliers to meet the financial obligation of paying their employees wage during the period they are on leave. Report by OECD in 2020 suggests that, many countries such as Japan, Korea, Portugal and Denmark have policies to motivate businesses to encourage their employees to proceed on annual leave during the period of COVID-19 in order to reduce employers' burden on meeting their employees wage bill. For instance, the Japanese Government through the Ministry of Health, Labour and Welfare provides financial support of up to JPY 8,330 per day to support employers pay their workers who are on annual leave. This means that in Ghana, hoteliers will be motivated to adopt the HR Strategy of encouraging their employees to proceed on annual leave if such financial assistance to businesses is provided.

In Germany, France, Belgium and Netherlands, the provision of Short Time Work (STW) policies by the governments have helped businesses to adopt the HR Strategy of reducing hours of workers in order to mitigate the financial burden on employees in terms of meeting their financial obligations. For instance, OCED report in 2020 shows that employees in Germany are given $60 \%$ of the difference in their monthly net earnings due to the employer reducing the working hours of their employees during periods of pandemic such as the COVID-19. It is therefore believed that if the Ghana Government can also adopt this STW policy, it will encourage hoteliers to adopt the strategies of reducing their employees working hours or converting the jobs of their employees to part-time during the pandemic period. Most of the time, the reluctance by employers to adopt most of the HR Strategies are due to the employers ethical reasoning that they may bring financial hardships on employees.

\subsection{Conclusions}

The hotel industry is one of the industries that is highly affected during period of pandemics as greater part of customers that patronized in the services of these hotels are international travelers. Industries that are affected during such pandemics tend to draw up HR strategies that will assist them meet their employees wage bill and also sustain their businesses. The study therefore had its main objective as assessing the HR strategies adopted by hoteliers in Ghana during the period of COVID-19. Though there are many strategies that are available for hoteliers to choose from during the pandemic, most firms in the hotel industry prefer laying off their employees as a key strategy to reduce their wage bill in order to survive during the turbulent period and rarely consider other HR strategies as important tool to assist them achieve their objective.

Just like any country where it is the duty of the government to provide good micro-environment for private businesses to flourish, the expectation of hoteliers in terms of government support for businesses in Ghana during the COVID-19 period needs improvement. Countries such as Australia, New Zealand, Portugal, France, Ireland, Japan, USA, and Canada have developed policies that will be enable businesses meet the wage bill of their employees during the period of pandemic. These policies provide support for businesses to implement any HR strategies in view of meeting their employees wage bill and sustaining their businesses during the period of COVID-19. Since these policies such as governments provision of short time work, financial support to workers whose working hours had been reduced, financial subsidies for employers to encourage employees go on annual leave, financial support for firms affected by drop in demand and supporting businesses to adopt information communication technology as alternative means of doing business are missing within the context of Ghana, hoteliers are constraint in terms of opting for other HR strategies and will consider laying off employees as the antidote to sustaining their businesses. 


\subsection{Empirical contributions and originality of the study}

The study looks at HR strategies adopted by hoteliers as a way of sustaining their businesses during the period of COVID-19. The coronavirus pandemic is novel and there is no literature on the various HR strategies businesses particularly hoteliers in Ghana are adopting in order to sustain their businesses in view of the numerous government restrictions by many countries and the highly drop in demand of services provided by firms in the hospitality industry. The study therefore serves as a foundation for other researchers to contribute to knowledge in the area.

Many governments as a way of protecting their citizens consider employees layoff as a rare option that businesses should adopt during pandemics to salvage their businesses but the study has revealed that if governments do not provide the necessary policies that will support the various HR strategies that are available for businesses, firms will always consider laying off employees as the best option to reduce their employees wage bill and sustain their businesses.

\subsection{Limitations and recommendations for future research}

There were many industries in Ghana that were affected by the coronavirus pandemic and it was worth considering all the industries to form the target population of the study. Again, the hotel industry is very broad and according to Novak (2017), it covers four main segments namely food and beverage, travel, and tourism, lodging and recreation. The study concentrated on only one segment of the industry which is hotels that provide lodging. It is therefore necessary that future research in this area should focus on other industries in Ghana or other segments within the hospitality industry in order for one to draw a broader conclusion on the various HR strategies adopted by firms in Ghana or in the hospitality industry during the period of the coronavirus pandemic.

There are many pandemics in the past, but the study considered the most recent one which was COVID-19 and looked at the various HR strategies hoteliers are adopting to sustain their businesses during the period of the pandemic. It is believed that studies should be conducted on pandemics in general taking into consideration, the Ebola virus outbreak, Coronavirus outbreak and the H1N1 influenza and the various HR strategies firms adopted to sustain their businesses during these periods.

\section{References}

Adu-Ampong, E. A. (2019). Historical trajectories of tourism development policies and planning in Ghana, 1957-2017. Tourism Planning and Development, 16(2), 124-141.

Agyeman, A. A., Laar, A., \& Ofori-Asenso, R. (2020). Will COVID-19 be a litmus test for post-Ebola Sub-Saharan Africa?. Journal of Medical Virology.

Asiamah, V. K. (2018). Factors that influence labour turnover intentions in the hospitality industry in Ghana. African Journal of Hospitality, Tourism and Leisure, 7(1).

Barua, S. (2020). Understanding Coronanomics: The economic implications of the coronavirus (COVID-19) pandemic (No. 99693). University Library of Munich, Germany.

Davidson, P.K (2016). Early retirement as strategy during pandemics, African Journal of Business and Management Research, 8(5)

Dewitt, S. (2017). Effects of pandemics on businesses: Europe perspective, Journal of Management Research, 2(3)

Forbes (2014). What Ebola means for businesses https://www.forbes.com/sites/riskmap/2014/08/ Accessed February 2020

Guildford, J.P. \& Fruchter, B. (1973). Fundamental statistics in Psychology and Education, New York, McGraw-Hill

Investor's Business Daily (2020). Dow Jones Today, Stocks Drop: Fed Stimulus; New York, California Lockdown; NYSE Floor Closes

Jamil, Z., Waheed, Y., \& Durrani, T. Z. (2016). Zika virus, a pathway to new challenges. Asian Pacific journal of tropical medicine, 9(7), 626-629.

Jones, P. (Ed.). (2002). Introduction to hospitality operations: An indispensable guide to the industry. Cengage Learning EMEA.

Koh, D. (2020). Occupational risks for COVID-19 infection. Occupational Medicine (Oxford, England), 70(1), 3.

Kongoley-MIH, P. S. (2015). The Impact of Ebola on the Tourism and Hospitality Industry in Sierra Leone. International Journal of Scientific and Research Publications, 5(12), 542-550.

Mensah-Ansah, J. (2011). Small tourism accommodation businesses in Ghana: A barrier to strategic tourism development? (Doctoral dissertation, Sheffield Hallam University,).

Mensah-Ansah, et al (2014). Tourism trends in Ghana: The accommodation sector. Tourism Analysis, 16(2), 157-168. 
Naktiyok, A. \& Halis, M. (2002). Organizational Downsizing: Investigating Effects on Survivors, Proceedings of International Science Conference in Modern Societies, OSH State University, June 17-18, OSH, 104-115

Novak, P. (2020). Hospitality Net: Four segments of the hospitality industry, Accessed January 2020

Ottenbacher, M., Gnoth, J., \& Jones, P. (2009). Identifying determinants of success in development of new high-contact services. International Journal of Service Industry Management.

OCED (2020), Supporting people and companies to deal with the COVID-19 virus: Options for an immediate employment and social-policy response, Accessed 30 March 2020

Partington, S. N. (2016). Hospitality employment. The routledge handbook of hospitality studies, 207.

Preko, A. K. (2020). The impact of tour services on international tourist satisfaction in Elmina, Ghana. International Journal of Tourism Cities.

Roughan, G. (2020). Government support for businesses by country, Unleashed, https://www.unleashedsoftware.com/blog/COVID-19 Accessed April 2020

Sarkodie, N. A.,\& Adom, K. (2015). Bridging the gap between hospitality/tourism education and hospitality/tourism industry in Ghana. International Journal of Research in Humanities and Social Studies, 2(7), 114-120.

Shuaib et al (2014). Ebola Virus Disease Outbreak-Nigeria, July-September 2015. Morbidity and Mortality Weekly Report (MMWR) 63 (39): 867-872

Shultz et al (1999). The Influence of Push and Pull Factors on Vocabulary and Involuntary Early Retirees' Retirement Decision and Adjustment, Journal of Vocational Behavior, 5(3)

Sirajudeen, M. S. (2020). Physical Therapy Management for Child with Generalized Joint Hypermobility. Majmaah Journal of Health Sciences, 8(1), 113-119.

Thunstrom et al (2020). The benefits and costs of flattening the curve for COVID-19. Available at SSRN 35619945.

Voykto, L. (2020). Coronavirus layoffs: Boeing lay off 6,770 workers amid pandemic, Forbes, Accessed April 2020

World Health Organization (2018). Global Outbreak Alert and Response Network (GOARN). Accessed on February 15th, 2020

Zehir, C., \& Savi, F. Z. (2004). A field research about implications of organizational downsizing on employees working for Turkish Public Banks, The Journal of American Academy of Business, Cambridge, 5(1): 343-349

Zeng, B., Carter, R. W., \& De Lacy, T. (2005). Short-term perturbations and tourism effects: The case of SARS in China. Current Issues in Tourism, 8(4), 306-322.

https://www.myjoyonline.com/business/economy. Accessed on the 16 April 2020 